Sonic Scope: New Approaches to Audiovisual Culture • Issue Three

\title{
Seeing Time Through Rhythm: An Audiovisual Study of Flicker Films
}

Martin Moolhuijsen

Published on: Oct 27, 2021

License: Creative Commons Attribution 4.0 International License (CC-BY 4.0). 


\section{ABSTRACT}

Seeing Time Through Rhythm: An Audiovisual Study of Flicker Films Martin Moolhuijsen, Universität der Künste, Berlin

The current essay will deal with flicker films, a sub-genre of structural film, that developed mostly in the United States during the 1960s. Through the analysis of the works of three different filmmaker and artists, namely Peter Kubelka, Tony Conrad and Paul Sharits, it is argued, through and intermedial approach, that their work operated a demystification of the whole cinematic apparatus while challenging the long held assumption of music as the major art of time. During my analysis particular emphasis will be given on compositional temporal strategies - i.e. how the single frames are organised - to audiovisual correspondences between vision and audition, and how three similar works that employ the same simple artistic strategy differ substantially on conceptual background, goal, scope and aesthetic result.

\section{Introduction}

Flicker films are a sub-genre of structural film that developed mostly in the United States during the 1960s. After a general introduction regarding structuralist and material filmmaking, I will delve into an analysis of the flicker as part of the cinematic apparatus. From that point on, once the necessary tools regarding historical and technical context have been outlined, I will conduct a comparative analysis of the contrasting approaches of three artists and filmmakers: Peter Kubelka, Tony Conrad and Paul Sharits. Even though the aesthetic results of their work differ substantially, they are all motivated by similar research on abstraction, rhythm and temporality that inevitably leads towards a deconstruction of the medium. For this reason, it is extremely interesting to compare three different artists whose work has explored a similar technique in approximately the same period, whilst apparently being unaware of each other. 1

My analysis will focus in particular on compositional temporal strategies. For instance, I will explore how single frames are organised, how sound and image 
correspond to each other, and how three works which share similar techniques differ substantially in regard to conceptual approach, the aims and scope of the work, and the aesthetic of the final result. Flicker films, I will claim, demystify film by questioning and exploring the limits of their medium: motion and linearity.

\section{Structural Film}

Before analysing the term 'structural film' and how this came to be the designated word to indicate the artistic output of a group of filmmakers that worked in the United States, it is necessary to contextualise the threads that through times, practices and technologies characterise the development of art forms. This essay therefore starts with a brief introduction to the early experiences of what came to be called absolute film or visual music.

In Europe, in the early years of the 20th-century, a group of artists including Hans Richter and Walter Ruttman were inspired to incorporate the innovations of abstract painting in the domain of film. $\stackrel{2}{\text { But }}$ if the effort of some abstract painters, such as Wassily Kandinsky and František Kupka, was to incorporate aspects of what within the western canon has always been thought to be the non-representational art par excellence, i.e. music, it still lacked one fundamental quality that painting did not have: a development over time. $\frac{3}{\text { Richter' }} \mathrm{s}$ and Ruttman' s films, respectively Rhythmus (1923) and Lichtspiel Opus 1 (1921), are to be considered among the first examples of abstract film, where abstract geometrical shapes move across a screen, coalesce, separate and dance according to the time development that film allows. They claimed their work to be an example of Malerei der Zeit: painting with time. $\frac{4}{\mathrm{~A}}$ further level of abstraction, where abstract geometrical shapes were no longer the focus of the film, was reached twenty years later by Dwinell Grant who in 1943 made Color Sequence, which is now considered one of the forerunners of flicker films due to its use of only monochromatic frames alternating in oscillating rhythms. $\frac{5}{5}$

When P. Adams Sitney, one of the key theorists of experimental film in the United States, chose to coin the term "structural film" to indicate a variegated group of filmmakers active in the 1960s, he defined the movement through four core, largely 
technical characteristics which included fixed camera positions, the flicker effect, loop printing and rephotography of the screen. $\underline{6}$

Defined most simply, "structural film insists on its shape, and what content it has is minimal and subsidiary to the outline ... It is a cinema of the mind rather than the eye" [emphasis added]. $\underline{7}$ While this may be true for most of the films produced by the filmmakers analysed by Sitney, such as Hollis Frampton and Michael Snow, it is somewhat contradicted by the statements that filmmakers Tony Conrad and Paul Sharits made about their own work. It is also important to notice that Peter Kubelka is not included within Sitney' s account of the structural film movement. Sitney acknowledges his role as a main precursor of flicker films and the whole movement in general, but for temporal and geographical reasons (Kubelka made most of his films in Europe and his work and research was already consolidated when he travelled in the United States in the 1960s) prefers to treat him separately from the group. Yet, a clear line can be traced between Kubelkas's, Conrad' s and Sharits' work, if not of direct influence, at least as a sign of zeitgeist, in the case of film as certain aesthetic peculiarities and artistic strategies that were perceived as necessary to be tackled within a wider cultural milieu at a given time.

Flicker films are works that employ mostly solid frames that alternate between highly contrasting images in terms of luminance and colour. For example, a flicker film may be constituted by a rapid alternation of black and white frames; however, a film composed of only a single black image, or one that slowly fades to black starting from a white image, would not necessarily fit within the flicker film style. In other words they emphasise the discrete, frame based structure of the filmstrip through light/dark or colour alternations. Furthermore they constitute the only sub-genre within the structural film movement to be mostly abstract. However, as Sitney suggests, the artistic output of the filmmakers associated with the group demonstrates an interest in the overall shape of the film which results in the very austere structures typical of the movement.

In his discussion about structural and materialist film Peter Gidal has pointed out how images in structural film simply are, they do not represent anything and therefore are devoid of any referential meaning. .8 He explains that:

signifiers approaching emptiness means merely (!) that the image taken does not have a ready associative analogue, it is not a given symbol or metaphor or allegory; that which is signified by the signifier, that which is conjured up by the image given, is something formed by past connections but at a very low key, not a determining or over-determining presence, merely a not highly charged moment of meaning. $\underline{9}$ 
Gidal continues identifying "duration as material piece of time [as] the basic unit [of all film]," out of which he further derives three different aspects of time: (1) real time, i.e. "time present as it is for the film-maker, denoted not connoted, at the stage of shooting, editing, printing, projecting, and interrelations of these" ; (2) illusionistic time, or the time of narrative used in much conventional Eisensteinian editing; and finally, (3) Einsteinian time, where there is no absolute value except for the "interaction of film moment and the viewer." 10 These aspects of time will be at the centre of my analysis, especially when intertwined with the compositional strategies that emerge from an evoked idea of time as it contrasts with the necessarily linear succession of single frames at a frame rate of 24 frames per second. In this regard, we will both see the films in their totality (and at that point we will have a better understanding of Sitney' s idea of structural film as a cinema of the mind) and in their atomic unit, which is the duration of the single frame.

But before being able to analyse Kubelka' s, Conrad' s and Sharits' work and the various strategies that give form to their films, it is useful to discuss the technical and conceptual implication of flickering as a fundamental characteristic of the analogue film projector.

\section{Rhythm and Flicker: Flicker as Movement and its Absence}

In an extremely interesting chapter called "Flicker and Shutter: Exploring Cinema' s Shuddering Shadow," film scholar Tom Gunning conducts a thorough analysis of the history of flickering and its importance within the cinematic apparatus. $\underline{11}$ 
At its most basic definition, cinema is a series of still pictures transformed into light that follow each other linearly at a constant rate which allows us to see the illusion of motion. Yet, the cinematic apparatus proves to be more complex than this simple statement. In order to project a film clearly, analogue film projectors employ a small device called shutter, which is a rotating disc divided into six triangles joined together at the centre with one missing every other triangle (see Figure 1). During the projection, the shutter works simultaneously with the shuttle, a toothed piece of metal that moves the film by its sprocket holes, obscuring the image every time that the shuttle pulls down

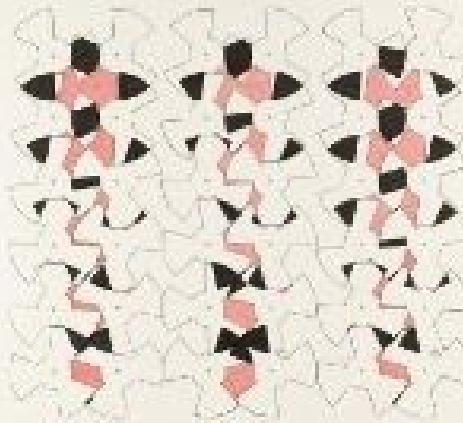

Figure 1. Paul Sharits, Hypothetical Shutter Interface Series B/J1. Image scanned from Ausstellung Paul Sharits. Eine Retrospektive, ed. Susanne Pfeffer (Museum Fridericianum, Kassel, 2014-2015), 17. the film. This prevents the viewer from seeing the vertical movement of the single frame being pulled down. The simple action of putting one image after another is not sufficient to see a film as we know it. In the projector, for example, if we move the film without a shutter we will see all the images following each other but they will be completely blurred vertically due to the movement of the film itself. In other words, we could say that what allows film to be movement is not so much the similarity between images, but rather the function of obscurity and discontinuity, which I shall explore shortly, and speed, i.e. time. This speed needs to be closer to what in psychophysics of vision is called "critical fusion frequency," a frequency of alternation that allows human vision to be continuous even if the light source is not. $\underline{12}$ Beyond film, other examples include fluorescent lamps or modern LED lighting which employ high flicker rates as a means to achieve overall continuity. $\underline{13}$ As Gunning brilliantly points out, "the flicker represents a new mastery of the flow of time and a manipulation of human perception through its interface with mechanical apparatuses, especially the automatic shutter. The shutter is a precision mechanism that can slice time into an instant, an increment of time basically beneath the threshold of human notice." 14

Flicker films employ the idea of the discontinuity of the frame as their structural basis. In other words, if the shutter is the device needed to achieve continuity and stability in the image, these films take advantage of its primary consequence, 
unaccessible to our perception: discontinuity. While the shutter's speed, beyond the fusion frequency, prevents our visual system to see its light/dark alternations, flicker films explicitly exploit this contrast to make the spectators aware of the nature of film, not by slowing the frequency of the shutter, but by emphasising the contrast between frames. It is therefore unsurprising that during the 1960s, when numerous artists were challenging the conventions of commercial cinema by deconstructing the cinematic apparatus, exploring the materiality of the filmstrip or breaking its representational conventions and narrative flow, that a new style which embraced these 'slices of time' emerged. But as soon as those 'slices of time' were unveiled, taking the role of the smallest unit of film, the question became: how are they to be organised? The following three sections, each dedicated to one of the filmmakers I am analysing, will offer an answer to this question, which is a compositional one.

\section{Peter Kubelka}

Peter Kubelka is a filmmaker particularly known for his reductive approach and careful planning of his films. In a 1966 interview with Jonas Mekas, the two artists reflected on the volume of Kubelka' s artistic output since he began making films in the early 1950s, comprising thirty-nine minutes of screen time, which is equal to two minutes of film per year, eight frames a day. $\underline{15}$

Kubelka is the son of a perfectionist virtuoso violinist who was intolerant of mistakes and who introduced his son to art and, in particular, music. Kubelka' s interest in film led him to study in Vienna and later at Rome' s Centro Sperimentale di Cinematografia where he made his first films. Inspired in part by the Second Viennese School of musical composition, Kudelka's work has consistently shown a predilection for precise and concise form. $\underline{16}$

Filmmaker Peter Tscherkassky has noted that since his earliest film Mosaik in Vetrauen (1955), Kubelka' s approach to editing shots incorporated musical techniques such as annoucing and repeating compositional themes. Furthermore, as Tscherkassky explains, montage is integral in the construction and affects of his work: 
If on initial viewing the impression arises of an unsolved jigsaw puzzle, disordered pieces lying all over the place, the placement of each element has actually been precisely determined and melds into an overall structure. At the expense of a story with a linear narrative, this method of montage stresses the meaning of the overall construction, a meaning that does not in effect disappear seamlessly and without a clue behind the story. There is a story, but one has to work at it, by thinking through the relationship of the individual part to the whole. $\underline{17}$

Mosaik in Vetrauen is still a representational film that has some loose sense of narrative, not due to how the shots merge with one another, but rather how they, as small unities, relate to the overall composition of the film. In his films Adebar (1957), Schwechater (1958) and Arnulf Rainer (1960), Kubelka explored these ideas more explicitly, gradually introducing techniques using increasingly smaller and more mathematically precise forms. He described these as "metrical film," in which the shot, hence movement, is no longer the basic unit of the film, but is replaced by the still picture, the photograph and the frame as the smallest possible unit. Whilst Adebar and Schwechater still demonstrate tendencies toward representation (albeit a completely flattened by the high contrast stock used to reverse the negatives), Arnulf Rainer moves toward the realm of pure abstraction.

Whilst the following analysis will be focused on the metrical structures of Arnulf Rainer, it is important to keep in mind that Kubelka's work is not purely formal, and although the materiality of the filmstrips is seldom mentioned in his conferences or writings, he still believed there was an irreducible quality to film that make his movies belong only to the medium of the acetate strip and the analog projector. He explains, "none of my films can be transferred to another medium because none of them would make any sense. No other media can convey the message of the works and the thoughts that they trigger. It has to be film or not at all." $\underline{18}$ This not only expresses one of Kubelka' s main concerns, which is film as an articulation of thought, untranslatable in any other medium, but also proposes an irreducible quality in search for a medium specificity of film. Shot in $35 \mathrm{~mm}$, Arnulf Rainer only maintains its impact in this format and when viewed, as per the instruction of the filmmaker, in a completely dark room with the volume set to the maximum. 


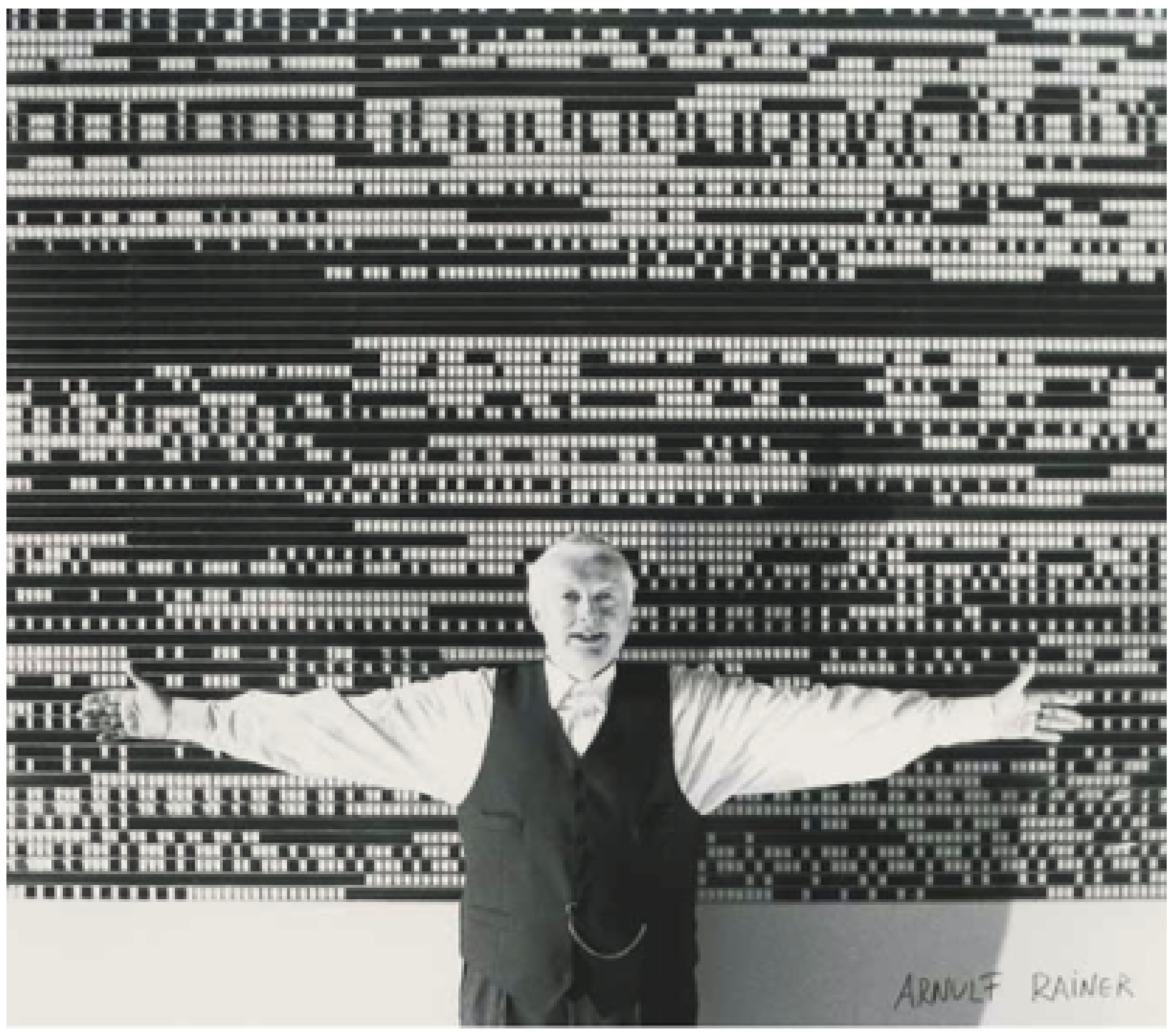

Figure 2. Peter Kubelka with a print of Arnulf Rainer.

Peter Tscherkassky, "The world according to Kubelka," in Film Unframed: A History of Austrian Avant-Garde Cinema, ed. Peter Tscherkassky (Vienna: Filmmuseum Synema Publikationen, 2012), 56.

Arnulf Rainer is based on only four elements: white (clear) frames, black frames, white noise and silence. It is composed of equal amounts of these four elements and is structured around what Kubelka coined "synch events" - instants in which two single elements (one visual and one auditory) collide with each other. Inspired by a trip to Africa where he experienced an ecstatic, synchronised moment when a single drum beat sounded at the exact moment that the sun set. $\underline{19}$ Cinema, he realised, could repeat and magnify this experience, speeding up the synch event to match the inherent underlying pulse of the projector at 24 frames per second. 
The term “synch event” used by Kubelka shares similarities with Michel Chion' s term "point of synchronisation" which indicates a "salient moment of an audiovisual sequence during which a sound event and a visual event meet in synchrony." $\underline{20}$ Both terms indicate a moment when two separate stimuli (one visual and one aural) merge. However, Chion' s synch points are mostly concerned with verisimilitude (which is not realism, but an apparent realism) of the sound/image relation. Whilst Chion' $s$ focus is not abstract films, he does suggest that synch points can "give the audiovisual flow its phrasing, just as chords or cadences, which are also vertical meetings of elements, can give phrasing to a sequence of music." 21 This latter sense of the term is more in line with Kubelka's "synch events" and the musicality of the techniques used in Arnulf Rainer.

Lasting only six minutes, Arnulf Rainer was assembled using four strips of equal length: one of clear leader, one of only black film, one with no sound and one with only white noise (see Figure 2). Kubelka, in his lectures, compared white noise to white light; white noise is the presence of all frequencies of the audible spectrum combined, in the same way as white light is the simultaneous presence of all the wavelengths of the visible electromagnetic spectrum. $\underline{22}$ The strips were then combined so that there would be a balance between white, black, sound and silence. Kubelka chose to generate mathematically all the possible combinations of these elements (white frame/silence, white frame/sound, black frame/silence, black frame/sound) based on combinations of 2, 4, 6, 8 and 12 frames. For instance, using the two frame sequence all the possible combinations are the following: 

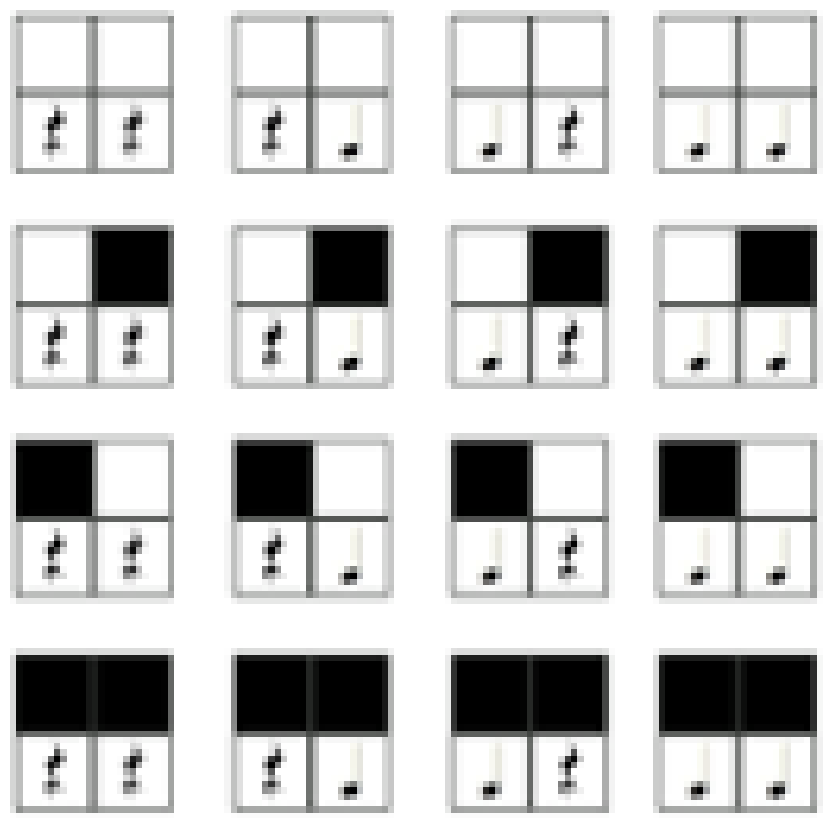

Legend:

- White Frame

- Black Frame

- Sound (white noise)

- Silence

Out of all the possible permutations he then selected a series of audiovisual themes based on lengths of 2, 4, 6, 8, 9, 12, 16, 18, 24, 36, 48, 72, 96, 144, 192 and 288 frames. While for the shortest frame series he was able to implement all the possible permutations, Kubelka decided not to explore them thoroughly with longer ones. $\underline{23}$ The film was then organised in 16 sections lasting 576 frames (24x24, the basic underlying pulse of film) which, given the lengths that Kubelka chose, could be divided by $288 \times 2=$ $576,192 \times 3=576,144 \times 4=576,96 \times 6=576$ and so on. He then chose material from the audiovisual pool of "themes" he had created and organised these with the longer theme

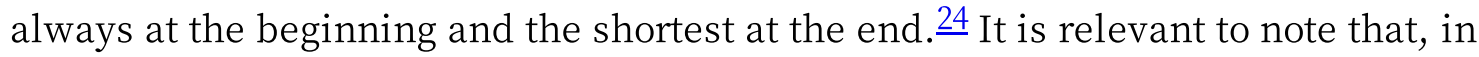
analogy with some of the pieces that stylistically belong to the Second Viennese School, the compositional principle is often occluded from the spectator. Upon viewing, Arnulf Rainer may look similar to a perfectly balanced modernist composition or painting, but the permutational structures - the sections and the phrases that constitute the film - are not discernable to the audience who, only upon studying the film frame by frame may finally grasp its formal construction.

Arnulf Rainer can be seen as the culmination of Kubelka' s work with metrical structures, in which he implemented all of light and darkness, all of sound and silence, emphasising the stillness between frames..$\underline{25}$ All the while he kept faith with his credo: 
"Cinema is not movement. This is the first thing. Cinema is not movement. Cinema is a projection of stills-which means images which do not move-in a very quick rhythm.” $\underline{6}$ This statement has inevitably led Kubelka to question the nature of cinemaas-movement which resulted in a revision of Sergei Eisenstein' s montage theory, which has, almost since the emergence of the medium, dominated its artistic and commercial manifestations. $\underline{27}$ In the "The Theory of Metrical Film" he explains:

It' $s$ just that Eisenstein wanted to have a collision-that' $s$ what he liked. But what I wanted to say is: Where is, then, the articulation of cinema? Eisenstein, for example, said it' $s$ the collision of two shots. But it' s very strange that nobody ever said it' $s$ not between shots but between frames [emphasis in original]. $\underline{28}$

In other words, with Arnluf Rainer Kubelka wanted to emphasise the difference between images rather than their similarity, exposing the inherent "intermittent frame structure of cinematography." $\underline{29}$ However, Kubelka' s film employs contrasting images as bursts of light and sound, but never sustains these articulations long enough to create the illusory effects commonly associated with flicker films. Hence Sitney's exclusion of the work from the genre of flicker films.

Kubelka has dialectically operated the six most basic elements of film, light/darkness, silence/sound, movement/stillness, to an apparent dead-end. Yet, deconstruction always resolves in construction, and flicker films moved away from an attempt to undermine the techniques of decoupage towards an exploration of the perceptual phenomenon of vision itself.

\section{Tony Conrad}

Tony Conrad approached film through a tortuous path. Trained at Stanford as a mathematician and interested in neurophysiology, he moved to New York at the beginning of the 1960s and immediately sought out avant-garde composer La Monte Young. Young was developing what at the time was called dream music, a form of music based on sustained tones and precise tuning that eschewed any linear development concerning form and was played for extended durations. Conrad took the role of the violist in the group and together with John Cale, Marian Zazeela and Young himself 
formed The Theatre of Eternal Music, also know as The Dream Syndicate. According to Conrad, the group' s music was:

Like Indian music, droningly monotonal, not even being built on a scale at all, but out of a single chord or cluster of more or less tonically related partials ... the heart of a symphony is a cadential formula-but dream music absorbs its own beginnings and endings, does not need to be startled, and lasts as long as its middle. $\underline{30}$

In this brief statement made by Conrad about the group' s music, we can already see preoccupations that he will transfer from music to film: the relationship between beginning and endings, the fact that it lasts "as long as its middle," the perceptual alterations, and his work with chordal structures and precise tuning, for which, given his background in mathematics, he devised a nomenclature system and helped the group with the experimentation of complex tuning ratios.

In opposition to Peter Kubelka' s Arnulf Rainer, Tony Conrad' s first film, The Flicker (1966), is concerned with perceptual hallucination. Although from a purely visual point of view the means that both artists employed in their respective works are substantially the same black and white frames, Conrad moved away from the permutational, abstract structures of Kubelka, whose intricacies were occluded from the spectator, and proceeded towards the possibility of recreating "the type of things that you see with your eyes closed." 31 It was this statement which led me to question the validity of Sitney' s definition of structural film. Such an emphasis on perception, albeit illusions, is in direct conflict with Sitney's statement about a cinema of the mind rather than the eye. Conrad' s wish of investigating "effects that act on your eyes so as to produce the actual imagery directly within the observer rather than in the normal way of having the eye interpret the light patterns," puts the ocular perception right at the centre of the film. $\underline{32}$ Nonetheless, when Sitney says "structural film insists on its shape" he understood that most structural films have a strong formal component that supports the work and, as is the case in The Flicker, as I will now explore. $\underline{33}$ Conrad began to work on The Flicker in 1965 when he started to experiment with a lensless projector at a friend' $\mathrm{s}$ house, notating flicker rhythms that would later be employed in the film. He noticed that:

The more vivid effects occur at frequencies below the lowest projector setting, yet some flicker of a gentle and satisfying type is found at this setting. The lowest setting was estimated at 14-17 f.p.s., the highest at 40-42 f.p.s. The approximate normal range is thus 15-40 f.p.s. In the artificially slowed flicker, ranging down to arbitrarily low frequencies, the hallucinatory effects were pronounced at 5-6 f.p.s., still good at 
4 f.p.s., though 4 seemed to be at the edge of the best effect. At 2 and 3 f.p.s., some effect remained, but most of the hallucinatory nature of the illusion disappeared. $\underline{34}$

He then compiled a set of 47 patterns running from 24 flashes per second to 3 and proceeded to assemble the film with only black and white frames, a work that would occupy every moment of his free time for months. $\underline{35}$ The soundtrack was composed using a homemade electronic instrument that produced a continuous series of clicks that slightly modulate their position over the stereo field and create a flow of rhythms that varies gradually and repetitively in spectral content and amplitude over the course of the 30 minute film. According to Branden W. Joseph, the influence of Stockhausen was decisive in the choice of the soundtrack. $\underline{36}$ The German composer had explained to Conrad how to work with stereo effects in order to generate a sense of aural vastness, furthermore between 1958 and 1960 Stockhausen had composed the tape piece Kontakte, where an illustrious moment toward the middle of the piece comprises of a descending glissando, which, as it goes down the harmonic spectrum reveals its true nature as rhythm rather than pitch. I am talking here about the pitch-rhythm continuum, or the fact that a rhythm sped up over the lower hearing threshold of $20 \mathrm{~Hz}$ is perceived by the human hearing system as pitch. $\underline{37}$ Stockhausen found a way to implement two parameters that traditionally have been separated from each other in musical composition; only with the help of the medium of the tape was he able to make the observation of a change in perception mediated by time and speed. As Joseph noticed, Conrad was very interested in this relation he had explored during a series of experiments with tape during 1959, and one of the notes in an early sketchbook of The Flicker states "for short cycles, gradual density changes are bought about by changing rhythms of cycles densities. Pulse rhythm composition (à la Kontakte).” $\underline{38}$ 
Conrad decided to open the film with a disclaimer (see Figure 3 ) that warned the audience of the possibilities of epileptic seizure upon viewing, due to the strong visual impact that the continuous alternation of stroboscopic, black and white images may have on particular viewers. This liability waiver is followed by the opening credits, presented in a psychedelic font and accompanied by the ragtime tune "Raggedy Ann." It is interesting here to notice that the disclaimer and the opening credits remain on screen for a considerable amount of time (three minutes). This led Lindley Page Hanlon to consider it merely "a sarcastic suggestion." $\underline{39}$ Conrad was aware that prolonged stasis would make the audience nervous and create expectation towards an event, something that would interrupt the apparently meaningless flow of time. His involvement in the New York scene of the 1960s where temporal suspension was common practice in experimental music. $\underline{40}$ Fluxus events, film (especially Andy Warhol' s films) and his own experience with The Theatre of Eternal Music, must have made him aware of the strong reaction and

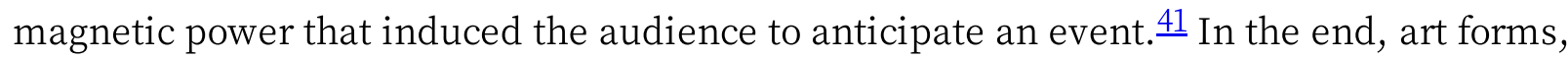
such as film or music, find themselves always, by their material necessity, social conventions and modes of presentation, suspended between memory and expectation, between what has happened and what is going to happen. How to disrupt this linear flow of experience was one of the objectives of the Theatre of the Eternal Music and of Conrad' s work in general. 
After these prolonged three minutes the film starts first with the presentation of the soundtrack and a white screen. As the "single blast of stereophonic buzz" slowly starts to "develop" and is articulated in swaying pulses which change in position and spectral characteristics, the white screen is interrupted by flashes of obscurity that gradually increase the rhythm of their presentation until, towards the centre of the film, fifteen minutes later, they reach an even rhythm of presentation (see Figure 4). $\underline{42}$ From that point on the black and white alternation slowly starts to approach the same rhythm as the beginning, in what we could call a discontinuous fade out of opposing and alternating frames. $\frac{43}{}$ As the vision of the audience is invested by the furious and growing intensity of the flickering light, visual illusions start to build up until they reach, together with the developing rhythm, the peak towards the centre of the film. Some people, during the first screenings of the film, have reported seeing colours but also representational imagery. $\underline{44}$

In his polemic answer to Adam P. Sitney' s definition, genealogy and categorisation of structural film, Fluxus artist George Maciunas has described The Flicker as belonging to the category of arithmetic and algebraic progression, characterised by a gradual change such as a crescendo or a diminuendo. $\underline{45}$ Maciunas opposes algebraic progression to the category of linear development, which he defines as linear progress such as a held image, or with the musical analogy of the tone. In contrast to Arnulf Rainer, where the film exists between the frames, or rather

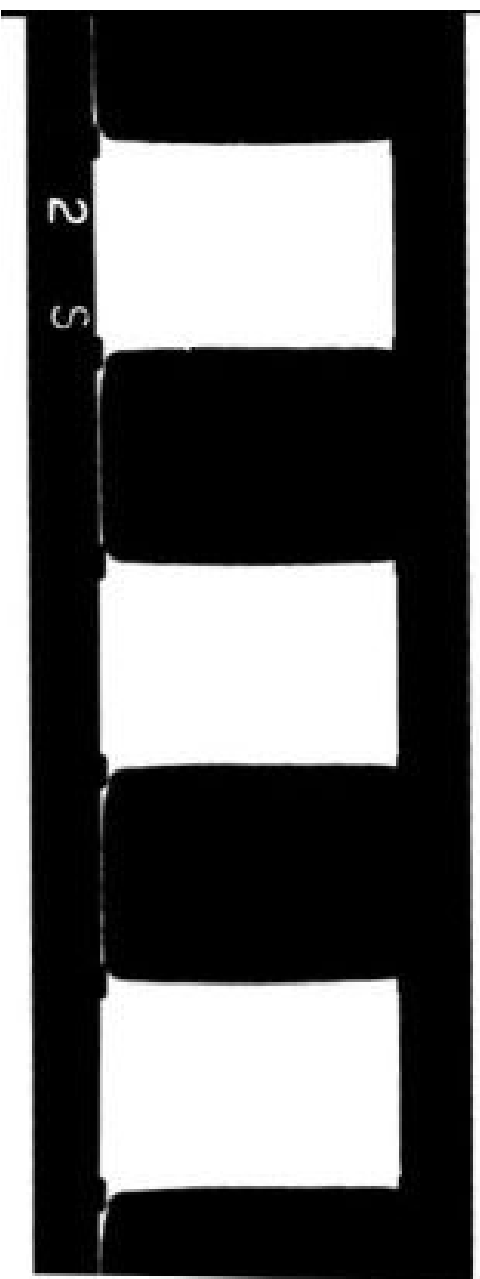

Figure 4. Black and White frames from The Flicker.

Image scanned from Branden W. Joseph, Beyond the Dream Syndicate. Tony Conrad and the arts after Cage (New York: Zone Books, 2008), 280. in the smaller pulse that is able to articulate sound and image, The Flicker distances itself from this idea and finds a fertile ground away from the screen and the instant, and into the eye and duration. The film is more than the sum of its parts, not only from a purely formal point of view where alternating rhythms are presented in a coherent structure recognisable from the audience, but also from an experiential point of view in the creation of illusions that exist within the audience' $s$ vision rather than on the screen. It responds to the same modality of perception that I 
mentioned earlier when talking about the pitch-rhythm continuum - a shift of perceptual category that changes through speed and rhythm, i.e. temporal articulation of matter. If we, for a moment, accept the classical definition of cinema as the illusion of movement mediated by speed and discontinuity provided respectively by the similarity between the images and the fast flicker of the shutter, then Conrad's The Flicker is the awareness of the absence of movement or the difference between the images mediated by speed and discontinuity. An awareness which realises itself in the union of perceptual phenomena between the eye and the brain by creating an illusion that does not exist on the screen. In this sense, The Flicker, can be seen as the simplest form of explanation and manifestation of what a film is traditionally thought to be.

While these preoccupations do not seem to appear among Conrad's thoughts at the time of making the film, while teaching media studies in the 1970s, he began to inquire into the nature of media and film in particular, in relation (and opposition) to linguistics. Conrad lamented the fact that:

the film scholar has never been up to dealing efficaciously with the problem of anticipation, suspense, temporal composition. This is nothing out of the ordinary: nobody (film scholars or makers, or the corresponding commentators and artists in any of the fields of music, dance, theatre, etc.) has been able to do much more than annotate the decision of taste which underlines temporal composition strategies [emphasis in original]. $\underline{46}$

This connects clearly not only with The Flicker, but with the social concerns that emerged during a later period of his life, in which Conrad explored how to regulate thinking itself by controlling attention in an effort to demystify how media manipulate their audience by controlling their expectations. We could, therefore, oppose the awareness of the illusion to the illusion itself, i.e. a film like The Flicker to a standardised use of representation and film by the commodity making entertaining industry. As Joseph notes: "The Flicker was thus perhaps the first work in a lifelong career to oppose an emerging force of regulation with a new type of thought." 47

\section{Paul Sharits}


Originally trained as a painter, Paul Sharits made his debut in the New York artistic scene when he joined Fluxus and participated in the production of Fluxfilms and Fluxboxes. At the time he was still an undergraduate studying painting and was divided between pursuing a career as a painter or as a filmmaker; unsure and doubtful about what he could add to the contemporary discourse about painting he pursued his interest in the temporal arts. He explains: "I had been doing 'abstract' painting, and at the same time I had been making 'normal' films, with people in landscapes. It was a kind of dichotomy. But then I stopped painting, and I was more interested in the temporal arts, ... anything that had a sequential aspect attracted my interest.” $\underline{48}$

Before talking about how Sharits implemented temporality and music analogies in his work with abstract art it is necessary to delineate some peculiarities of his art that set it aside from the work of Conrad and Kubelka. First of all, Sharits' flicker films employ colour and are not based exclusively on black and white frames. Second, if Kubelka and Conrad stopped using flicker after their major works with this technique, Sharits continued to explore the relation of temporality, colour and single frame images in a series of films, para-cinematic works such as the Frozen Film Frame (c.1971-1976) and installations that he termed "locational installations." $\underline{49}$ Third, not all of Sharits' s flicker films are completely abstract, there are some interspersed representational images in Peace Mandala/End War(1966), N:O:T:H:I:N:G(1968) and T,O,U,C,H,I,N,G(1968); among his early flicker films only Ray Gun Virus (1966) contains only pure colour frames. At first glance this may seem problematic in the context of having analysed only abstract film so far, especially as Sharits describes Ray Gun Virus as a narrative film. Birgit Hein, the filmmaker and curator who invited Sharits to the contemporary arts exhibition Documenta 6 in 1976, has described Sharits' approach to narrativity as being concerned not with story, which was epitomised by Hollywoodstyle cinema, but rather with an "horizon of expectation," in other words, a simple progression in time which film could not eschew, being defined by the same flow of still images in a linear vector. $\underline{50}$ P. Adams Sitney, who by admission had limited respect for Sharits' art at the beginning of his career, has criticised his use of images, claiming that:

the dilemma of Sharits' $s$ art has turned on the failure of his imagery to sustain its authority in the very powerful matrix of the structures he provides. His search for metaphors and icons for the particular kind of cinematic experience that his films engender has not been as successful as his invention of markers to reflect the duration of his films. $\underline{51}$ 
Gidal, as quoted in Malcolm Le Grice' s "Abstract Film and Beyond,” having a similar opinion to Sitney, defines Sharits' work concerned with three major ideas: "The first is the obvious factor of color interactions in time, which affect the retina; the second is a confusing romanticism which results in unintegrated images and inappropriate interpretation of the material aspect of the experience; the third is a systemic intention in the overall form of his film. The interesting interaction is between the first and last." $\underline{52}$ Both Sitney and Gidal quickly dismiss Sharits' use of representational images defining it as "a dilemma" and "uninteresting." So, while Conrad lamented the fact film critics and film theory relied too much on semiotic and representational analysis, the major theorists of structural and material filmmaking criticised Sharits for employing representational images in his films. Avant-garde critics searched for a pure selfreflexive, material definition of the practice of various artists that was too reductive to encompass the whole spectrum of cinematic expressions of that time. Sharits felt excluded, especially in the moment in which Sitney defined his work as immature. As Branden W. Joseph notices, “even now, structural film' s identification with what Peter Gidal termed 'low level signifiers' has remained so hegemonic that even overtly revisionist approaches unquestioningly reiterate the genre' s rejection of subjective expression and social reference in favour of the contemplation of 'film as film'." $\underline{53}$ This led Sharits in 1970 to write a letter to Sitney and to propose a film-theory course that would make "a critique of your concept of 'structural' film." $\underline{54}$

This brings us to another important characteristic of Paul Sharits' work: the fact his films are expressive. Unlike the films by Kubelka and Conrad, in which there is no direct intention of expression, Sharits' early films contain various emotionally charged, strong images which reflect directly his psychological and psychophysical state. Sharits' early work never seemed to accept completely this dichotomy between expressiveness and inexpressiveness, representational images and pure abstraction. Being in between these two opposing worlds, he did not manage to abandon his formal and inexpressive structures, nor of the personal experiences shaping his work. While structuralist and materialist film critics have seen this as his major problem, and largely ignored a reading of his work which included expression and representation, I think that is exactly in the light of this dichotomy that Sharits' work needs to be seen; especially considering the fact that it is around 1970, the period in which the aforementioned comments were published, that he stopped making expressive work and dedicated himself mostly to a materialist research. Finally, he came back to terms with his desire for representation and expression in the mid 1970s and was able to work comfortably between these two, apparently, opposing poles. 
Among his early flicker films I would like to focus on what Sharits termed Mandala films, which are Peace Mandala/End War(1966), N:O:T:H:I:N:G(1968)

and T,O,U,C,H,I,N,G(1968). I am particularly interested in the relationship between $N: O: T: H: I: N: G$ and T,O,U,C,H,I,N,G. P. Adams Sitney considered $N: O: T: H: I: N: G$ the first mature work by Sharits and described it with the terms that he deemed appropriate for a structuralist work:

The ultimate aspiration of Sharits' cinema must be the synthesis of whiteness; because the natural effect of his blazing colors is a blending that will always tend towards bleaching. In Ray Gun Virus the bleaching affected me as a weakness, but in $N: O: T: H: I: N: G$, the related contextual images and the sound, as well as the title, utilize the theme of evaporation (which is the converse of potentiality, which is the mode of all structural film). $\underline{55}$

Here Sitney makes an interesting observation, he underlines the blending of the different colours in time: Sharits was extremely interested in perception and wanted the audience to have an ecstatic experience of his work. Sitney championed N:O:T:H:I:N:G as Sharits' most exemplary film because it followed the "mode of all structural film," meaning that the shape of a film is more important that its content, which is just "subsidiary to the outline." $\underline{56}$ Furthermore the film does not contain any of the erotic or violent images that characterise much of Sharits' other work. Sharits' seems to back up this interpretation of his work, as he defined $N: O: T: H: I: N: G$ as "a film that will not 'mean' something-it will 'mean,' in a very concrete way, nothing." 57

It is extremely important to say that all of the early mandala films have a circular structure. This was employed by Sharits both as a means to break the linear continuity as well as to imitate the experience of the mantra in buddhism:

I am more interested in the mantra because, unlike the mandala and yantra forms which are full of such symbols, the mantra is often nearly pure non-sense-yet it has intense potency psychologically, aesthetically and physiologically ... the simple "Om" - a steady vibrational hum. I' ve tried to compose the center of $N: O: T: H: I: N: G$, on one level, to visualise this auditory effect. $\underline{58}$

Sharits had studied music as a child and often in his early writings cited works by Corelli, Bach and Beethoven. Often, he advocated for a cinema in which both sound and image could be considered as separate, autonomous entities able to develop their independence, criticising the use of sound as supportive element of the image especially in the "lip synch of anthropomorphic works." $\underline{59}$ Far from suggesting a literal, and 
always unsuccessful, analogy between colour and sound, Sharits' films employ musical ideas and try to visually replicate the experience of aural elements such as a complex tone or a chord. $\underline{60}$ Sharits did not want to create a mimetic translation, but rather work with structures that would allow the same treatment of the material, such as the frame (as partial) organised in bursts of colour (as tones or chords), arranged in filmstrips (as compositions) and therefore being able to organise the visual material in phrases and sections, always with the awareness that this comparison would be "suggested" and never fully achievable. $\frac{61}{}$ In his early flicker films the single colour frames blend toward whiteness while still insisting on their discreetness: the resulting effect was paralleled by Sharits with that of a tone. Whenever we hear a tone we don' t hear every single partial contained in it, but we rather perceptually group the sound as a whole. His use of colours and precise rhythms mimics this perceptual characteristics while emphasising certain aspects that are specific to film, in particular its frame discreetness.

Sharits developed these comparisons in great measure in a later part of his career in different artworks such as the Frozen Film Frame, Locational installations and Trascriptions, but here I would like for two important reasons to focus more on $T, O, U, C, H, I, N, G$. First of all, the movie was realised in the same decade as the other two films I have been discussing so far. $\underline{62}$ Both critics and Sharits consider it a flicker film. Second, as we will see, T,O,U,C,H,I,N,G contains almost all the topics that we have discussed so far: the tension between rigid structure and subjectivity, abstraction and representation, rhythm (as atomic unit) and wholeness, relationship between sound and image, as well as questioning fundamental characteristics on the ontology of cinema. In this sense, I do not agree with Sitney who considers $N: O: T: H: I: N: G$ the most exemplary film of Sharits' s early phase, and, following Branden W. Joseph, I would like to propose $T, O, U, C, H, I, N, G$ to have that role. $\underline{63}$ 


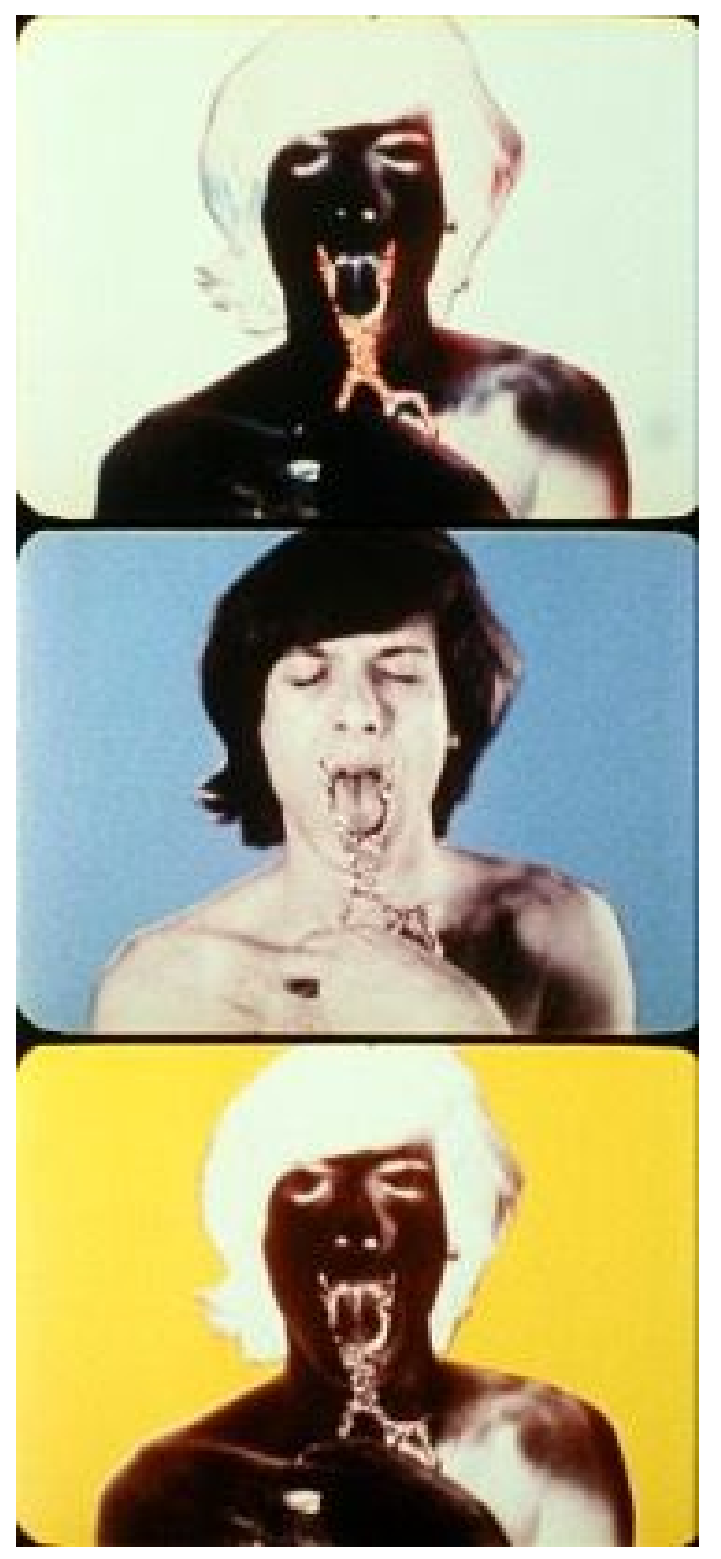

Figure 5. Stills

from $T, O, U, C, H, I, N, G$ (Paul Sharits, 1968).

Image taken from Canyon

Cinema, accessed November 1, 2020,

https://canyoncinema.com/2020/0 4/02/now-available-new-print-ofpaul-sharits-touching/.

Figure 5). $\underline{64}$
Lasting 12 minutes, T,O,U,C, H,I,N,G(1968) is the last of the mandala films. The film starts with an enunciation of the letter $\mathrm{T}$, after which a section of the film is articulated before presenting the letter $\mathrm{O}$, then a section, then a $\mathrm{U}$ and so on until the $G$ appears on the screen declaring that the film is over. As mentioned before, the film contains among the most emotionally charged and aggressive images to appear in a movie by Sharits. For larger part of the film, the representational images alternate between a still picture of the poet David Franks with his tongue placed between the two blades of a pair of opened scissors and his face being scratched by a hand coming from the side of the frame, that flicker in both positive and negative giving an impression of interrupted movement. At times the scissors appear to be moving towards the tongue while other time they appear to be moving away, this is of considerable importance considering that the image that conveys this movement is the same in both cases. By placing it before or after the image of the tongue between the scissors, Sharits creates a sort of palindromic movement, where the same image acquires both functions. As Rosalind Krauss has noticed, the image of the scissors, beside being a reference to Dali' $s$ and Buñuel's Un Chien Andalou (1929), does not only provide a powerful and effective metaphor for the act itself of isolating a single frame and cutting a film, but also describes Sharits' physical and material intentions towards the spectator: a moment of sublimated violence (see 
Violence which is also conveyed by the continuous flicker of the background or of the pure colour frames. The hues present in the film circle mostly around shades of a saturated red, a light purple, a pale yellow and orange and blue. Colours in the area of greens appear only when fast, almost too fast to be clearly understood, images of what seems to be a surgery and a sexual act appear on screen. The scissors metaphor also provides some insight on the use of the soundtrack. The audio track is composed exclusively of a low percussive sound that gradually accelerates towards the middle of the movie (in the same way that the flicker rhythm does) and of a repetition of the word "destroy." Sharits had noticed that when a word is repeated, omitting the natural pauses between each repetition, the word will start first to lose its meaning and then each person would hear the sound morph into other words. $\underline{65}$ This illusion was discovered in those same years by the researchers Richard and Roslyn Warren who called it "verbal transformation effect." 66 While the Warrens concluded that the variations of the word change based on the individual, and are therefore not predictable, Sharits thought that some recurring words, influenced by the patterns of flickering images, i.e. the rhythm of the image influencing the rhythm of the word, would arise among different people. $\underline{67}$ In this sense the retinal fusion of colours provided by the alternating coloured frames with its perceptual phenomena is transposed in the realm of sound, where a rhythmical word, whose rhythm according to Sharits corresponds to the pulse of the projector, gradually appears to be changing throughout the whole film. $\underline{68}$ Here again, the image of the scissors that are on the brink of cutting a tongue becomes the perfect metaphor. They do not only refer to the single frame, the violent sexual imagery, the suspension of linear temporality, but also to the act of cutting recorded speech in a manner analogous to William Burroughs' s cut-up techniques that Sharits often referenced. $\underline{69}$ Furthermore, the title itself refers to the whole idea of cutting, the commas that are placed between the single letters of the word touching are a direct attempt to render this basic, simple tape and film technique as a means to render the single unit, the frame, as a coherent whole. Whenever we read a word, we don' t observe every letter of it, but we perceive the sound-image as a whole to which we assign a meaning. It is in this sense that Sharits' movie needs to be seen: in the relation between signifier and signified, frame and filmstrip, materialist and subjective approach. A purely structural and materialist or a semiotic analysis can not grasp the film in its totality.

Most of the films of Sharits' early work (and also of its purely analytical phase of the mid 1970s) are notated (see Figure 6). Sharits would notate all the frames, one by one, with colours, in a laborious work that would often take him months to complete. The sketches and notations were both intended as an aid to the compositional process of 
creating the film, as well as an atemporal material realisation of it. This twofold aspect is brilliantly exemplified in the title of a talk by Tony Conrad about Paul Sharits: between "prescription and collapsed temporality," between instructions to be followed (as in a musical score) and the flatness of the page that allows the totality of the work to be experienced at once. $\underline{70}$

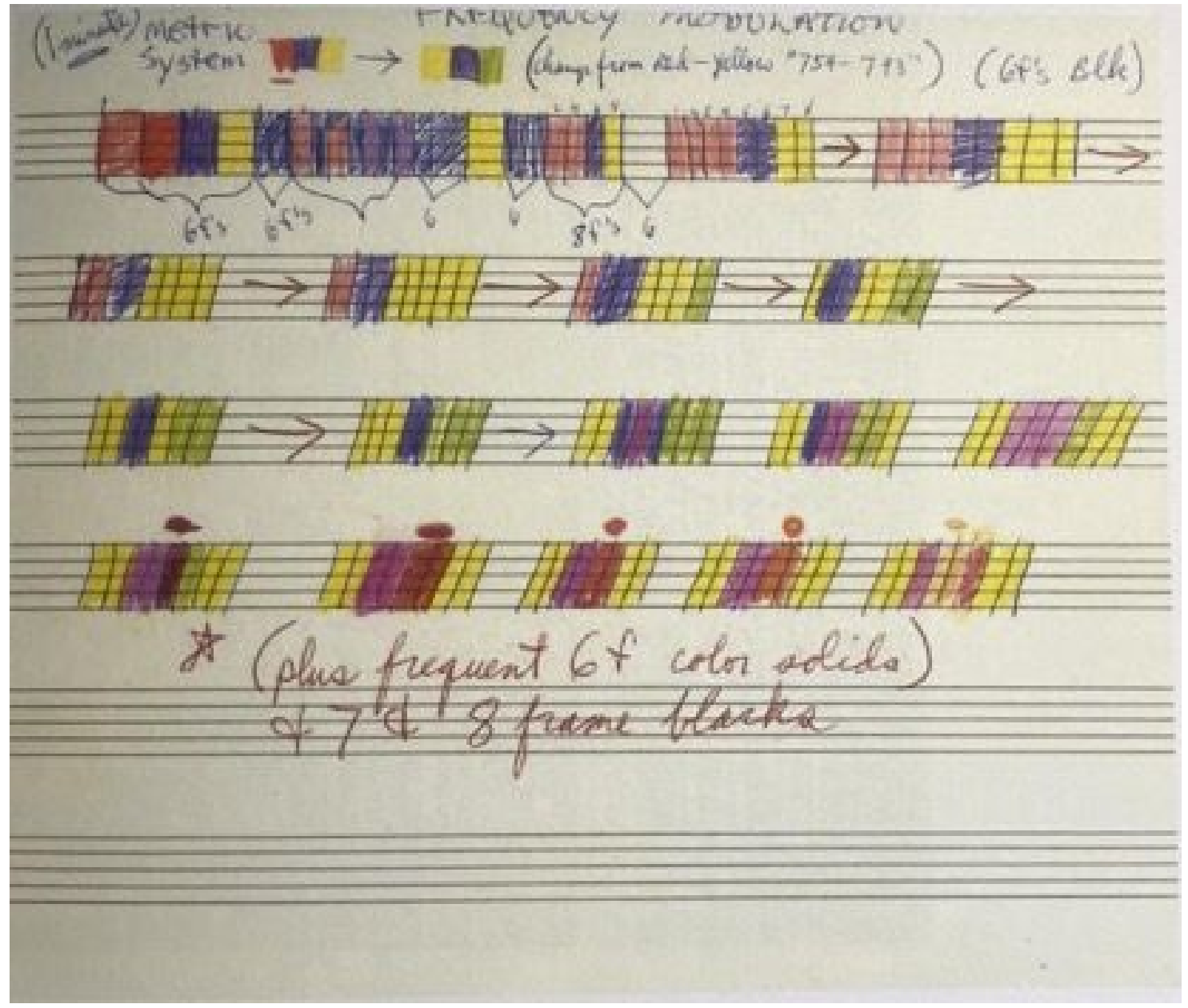

Figure 6. Paul Sharits' sketch for N:O:T:H:I:N:G (Paul Sharits, 1968), no date, Paul Sharits Archives at Burchfield Penney Art Center, Buffalo, NY. Gift of Christopher and Cheri Sharits, 2006.

Image scanned from Ausstellung Paul Sharits. Eine Retrospektive, ed. Susanne Pfeffer (Museum Fridericianum, Kassel, 2014-2015), 51.

Yet, in a manner somehow analogous to Kubelka' s Arnulf Rainer, the compositional principles are occluded from the spectator, who cannot understand them by simply watching the film. It might be this reason that pushed Sharits to present his films as Frozen Film Frame, where filmstrips of equal length are ordered vertically adjacent to each other and placed between two sheets of plexiglass. Here the time of the projector, that steady pulse that has been so prominent throughout this whole essay, leaves space 
(time?) for the viewer' s phenomenological experience of it. Spectators, guided by the verticality of the sprocket holes at the sides of the film strips, are able to follow the film both linearly, as well as having a comprehensive understanding of its structure in a blink of an eye. A collapsed temporality that brings the smallest fragmental unit into dialogue with the totality of a work, and, finally, the experience of time in the realm of the purely visual (see Figure 7).

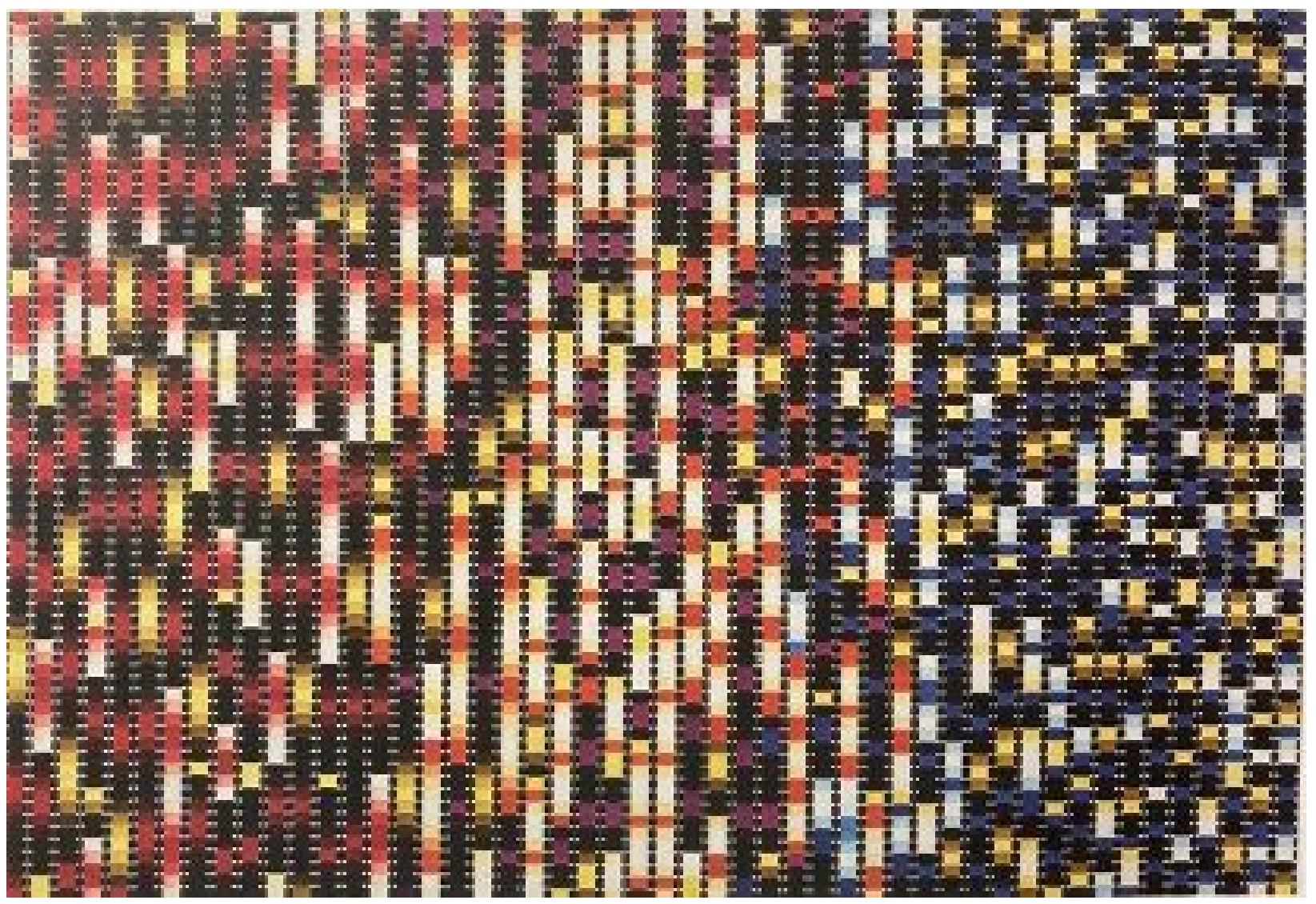

Figure 7. Paul Sharits. Frozen Film Frame. c.1971-1976.

Image scanned from Ausstellung Paul Sharits. Eine Retrospektive, ed. Susanne Pfeffer (Museum Fridericianum, Kassel, 2014-2015), 114.

\section{Conclusions}

In western cultures music has widely been seen as a non-representational art that had a peculiar relationship with temporality in the way that it "exploits the sense of the integration of a flux of events into a single, unified whole." $\underline{71}$ The early innovations of European abstract film tried to challenge this position by extending the concerns of film 
and painting beyond what traditionally they have been thought to be able to accomplish. Flicker films were developed in a period in which not only were these concerns reemerging, but also when filmmakers and critics were trying to establish a filmic art able to reach the same degree of self reflexivity that a "truly modern" art was deemed to exhibit. In doing so, they questioned the ontology of their own medium, providing a basis for the dematerialisation of cinema and the later forms of para-cinematic expression. Kubelka' s questioning of the nature of editing, Tony Conrad' s exploration of power relationships and visual illusions, and Paul Sharits' efforts to implement the perceptual characteristic of a tone in pure colour frames and to exhibit the temporality of film without the necessity to project it, have proven to be some of the most successful strategies to explore "film as film" by "extracting the ghost from the guts of the machine and relating it to the essential principle of demystification - that cinema is not the movement of images, but rather a light vibration." $\underline{72}$ This essay, therefore, has not only highlighted the differences and the similarities between these three artists, but it has also underlined how the implementation of techniques and ideas from another art form proves to be a successful strategy for expanding the conception of a medium beyond its perceived limitations.

\section{Bibliography}

Alperson, Philip. “'Musical Time' and Music as an 'Art of Time' ." The Journal of Aesthetics and Art Criticism 38, no. 4 (Summer, 1980): 407-414.

Chion, Michel. Audio-Vision: Sound on Screen. Translated by Claudia Gorbman. New York: Columbia University Press, 1994.

Daniels, Dieter, and Sandra Naumann, eds. See This Sound: Audiovisuology. Köln: Verlag der Buchhandlung Walther König, 2015.

DeJong, Constance, and Andrew Lampert, eds. Tony Conrad: Writings. New York: Primary Information, 2019. 
Dicker, Barnaby. "Twenty-First Century Flicker: Jodie Mack, Benedict Drew and Sebastian Buerkner." In Experimental and Expanded Animation: New Perspective and Practices, edited by Vicky Smith and Nicky Hamlyn, 61-78. London: Palgrave Macmillan, 2018.

Eisenstein, Sergei. Film Form: Essays in Film Theory. Translated and edited by Jay Leyda. New York: A Harvest/HBJ Book, 1977.

Encyclopedia Britannica. "Human Eye - Flicker." Britannica.com. Accessed May 11, 2021. https://www.britannica.com/science/human-eye/Temporal-summation\#ref531587.

Gidal, Peter. Structural Film Anthology. London: British Film Institute, 1978.

Gunning, Tom. "Flicker and Shutter: Exploring Cinema' s Shuddering Shadow." In Indefinite Visions: Cinema and the Attractions of Uncertainty, edited by. Martine Beugnet, Allan Cameron, and Arild Fetveit, 53-69. Edinburgh: Edinburgh University Press, 2017.

Joseph, Branden W. Beyond the Dream Syndicate: Tony Conrad and the Arts After Cage. New York: Zone Books, 2008.

Le Grice, Malcolm. Abstract Film and Beyond. Cambridge: MIT Press, 1977. Maciunas, George. “On 'Structural Film' (by P. Adams Sitney)." Film Culture Reader, edited by P. Adam Sitney, 349-350. (New York: Cooper Square Press, 2000.

Mekas, Jonas, ed. Film Culture, No. 65-66 - 1978: Paul Sharits. Montpelier, Vermont: Capital City Press, 1978.

Mekas, Jonas. Conversations with Filmmakers: Movie Journal Columns 1961 1975. Leipzig: Spector Books, 2018.

Nyman, Michael. Experimental Music: Cage and Beyond. Cambridge: Cambridge University Press, 1999.

Pater, Walter. “The School of Giorgione." Victorianweb.org. Accessed October 18, 2020. http://www.victorianweb.org/authors/pater/renaissance/7.html.

Pfeffer, Susanne, ed. Ausstellung Paul Sharits: Eine Retrospektive. Kassel: Museum Fridericianum, 2014-2015. 
Sánchez, Esperanza Collado. Paracinema. La Desmaterialización del Cine en las Prácticas Artísticas. Arte y Derecho, Trama Editorial, S.L., 2013. Kindle

Sitney, P. Adams, ed. The Avant-Garde Film: A Reader of Theory and Criticism. New York: New York University Press, 1978.

Sitney, P. Adams. "Structural Film." In Film Culture Reader, edited by P. Adams Sitney, 326-348. New York: Cooper Square Press, 2000.

Sitney, P. Adams. Visionary Film: The American Avant-garde, 1943-2000. New York:

Oxford University Press, 2002.

Stockhausen, Karlheinz. "The Concept of Unity in Electronic Music." Translated by Elain Barkin. Perspectives of New Music 1, no. 1 (Autumn, 1962): 39- 48.

Tscherkassky, Peter ed. Film Unframed: A History of Austrian Avant-Garde Cinema. Vienna: Filmmuseum Synema Publikationen, 2012.

Warren, Richard M. and Roslyn P. Warren. "Auditory Illusions and Confusions.” Scientific American 223, no. 6 (December 1970).

\section{Media Cited}

Adebar. Peter Kubelka. Film. Austria: 1957.

Arnulf Rainer. Peter Kubelka. Film. Austria: 1956.

Color Sequence. Dwinell Grant. Film. USA: 1943.

Lichtspiel Opus 1. Walter Ruttmann. Film. Germany: 2021.

Mosaik In Vertrauen. Peter Kubelka. Film. Austria: 1955.

N:O:T:H:I:N:G. Paul Sharits. Film. USA: 1968.

Peace Mandala/End War. Paul Sharits. Film. USA: 1966.

Ray Gun Virus. Paul Sharits. Film. USA: 1966. 
Rhythmus. Hans Richter. Film. Germany: 1921.

Schwechater. Peter Kubelka. Film. Austria: 1958.

T,O,U,C,H,I,N,G. Paul Sharits. Film. USA: 1968.

The Flicker. Tony Conrad. Film. USA: 1966.

\section{Biography}

Martin Moolhuijsen is an Italian interdisciplinary artist based in Berlin.

His work takes the form of installations, fixed-media pieces, conceptual artworks, texts and video and tries to encompass the whole spectrum and potentiality of sound and its peculiarities as expressed by different media.

His work has been presented at Akademie der Künste, Deutschlandfunk Kultur, ZKM Zentrum für Kunst und Medien and CTM Vorspiel among others.

In 2021, he has been awarded the Honorary Mention at the Fourth International Student Biennial for his single copy performative record "Infinite Jest."

He holds a BA in Drama, Art and Music Studies from the University of Bologna and is currently finishing a MA in Sound Studies and Sonic Arts at the Universität der Künste in Berlin.

\section{Footnotes}

1. 
P. Adams Sitney, "Structural Film," in Film Culture Reader, ed. Adams P. Sitney (New York: Cooper Square Press, 2000), 343;

P. Adams Sitney reports that Conrad had not seen Kubelka's films before completing The Flicker,

Paul Sharits, "Ray Gun Virus and Other People' s Flicker Films," in Ausstellung Paul Sharits. Eine Retrospektive, ed. Susanne Pfeffer (Museum Fridericianum, Kassel, 20142015), 260;

Paul Sharits says that he was not aware of both Kubelka's and Conrad' s work until Ray Gun Virus was finished. $\_$

2. Marcel Schwierin and Sandra Naumann, "The Musicality of Abstract Film," in See this Sound: Audiovisuology: A Reader, ed. Dieter Daniels and Sandra Naumann (Köln: Verlag der Buchhandlung Walther König, 2015), 18-31. 3.

Andrea Gottdang, "Painting and Music," in See this Sound: Audiovisuology: A Reader, ed. Dieter Daniels and Sandra Naumann (Köln: Verlag der Buchhandlung Walther König, 2015), 249-250; Far from trying to legitimate their work as a direct translation between music and painting, these artists were nonetheless inspired by music and directly referenced it in many of the titles of their paintings;

I am referring here to the echoes of Walter Pater' s famous sentence, "All arts constantly aspire to the condition of music. For while in all other kinds of art it is possible to distinguish the matter from the form, and the understanding can always make this distinction, yet it is the constant effort of art to obliterate it." Walter Pater, "The School of Giorgione," accessed October 18, 2020, http://www.victorianweb.org/authors/pater/renaissance/7.html.

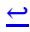

4. Schwierin and Naumann, "The Musicality of Abstract Film," 18-31.

5. Ibid. $\doteq$

6. P. Adams Sitney, Visionary Film: The American Avant-garde, 1943 - 2000, (New York: Oxford University Press, 2002), 348.

7. Ibid., $348 . \pm$ 
8.

Peter Gidal, Structural Film Anthology (London: British Film Institute, 1978), 1;

Further developing Sitney's definition of structural film, Gidal defines structural/materialist film as "deal[ing] with devices that result in demystification or attempted demystification of the film process." In other words, he emphasises the deconstructive aspects of these films, rather that categorising them starting from the four characteristics that Sitney had established. $\bullet$

9. Gidal, Structural Film Anthology, 7-8. $匚$

10. Ibid., 8-9.

11. Tom Gunning, "Flicker and Shutter: Exploring Cinema's Shuddering Shadow," in Indefinite Visions: Cinema and the Attractions of Uncertainty, eds. Martine Beugnet, Allan Cameron, and Arild Fetveit (Edinburgh: Edinburgh University Press, 2017), 53-69. $\Xi$

12. “Human Eye - Flicker,” Encyclopedia Britannica, accessed May 11, 2021, https:/www.britannica.com/science/human-eye/Temporal-summation\#ref531587. 13. Depending on the age and the model of the projector and the shutter, the flicker rate in film could be two or three times more than the frame rate. For instance, at the speed of $24 \mathrm{fps}$, it could be 48 or 62 .

14. Gunning, "Flicker and Shutter," $57 . \leftrightharpoons$

15. Jonas Mekas, Conversations with Filmmakers: Movie Journal Columns 1961 1975 (Leipzig: Spector Books, 2018), 62.

16. Peter Tscherkassky, "The world according to Kubelka," in Film Unframed: A History of Austrian Avant-Garde Cinema, ed. Peter Tscherkassky (Vienna: Filmmuseum Synema Publikationen, 2012), 58.

17. Ibid., $72 . \unlhd$

18. Ibid., $81 . \subseteq$

19. Peter Kubelka, "The Theory of Metrical Film," in The Avant-Garde Film: A Reader of Theory and Criticism, ed. P. Adams Sitney (New York: New York University Press, 1978), 158. 
20. Michel Chion, Audio-Vision: Sound on Screen, trans. Claudia Gorbman (New York: Columbia University Press, 1994), 58.

21. Ibid., $59 . \Perp$

22. Kubelka, "The Theory of Metrical Film," 159.

23.

Tscherkassky, "The world according to Kubelka," 72;

As Peter Tscherskassky notices, 12 frames would have generated 4,096 possible frame combinations, alone resulting in a film of 34 minutes in length. $\subseteq$

24. Ibid., 72-75. $\subseteq$

25. Kubelka would then explore further synch events in his film Unsere Africa Reise (1966), a representational film in which he abandoned metrical permutations in favour of the metaphors that the synch events could create. $\_$ 26. Kubelka, "The Theory of Metrical Film," $140 . \Perp$ 27. "Shot and montage are the basic elements of cinema. Montage has been established by the Soviet film as the nerve of cinema. To determine the nature of montage is to solve the specific problem of cinema. The earliest conscious film-makers, and our first film theoreticians, regarded montage as a means of description by placing single shots one after the other like building blocks. The movement within these building-block shots, and the consequent length of the component pieces, was then considered as rhythm. A completely false concept! This would mean the defining of a given object solely in relation to the nature of its external course. The mechanical process of splicing would be made a principle. We cannot describe such a relationship of lengths as rhythm. From this comes metric rather than rhythmic relationships." From Sergei Eisenstein, "A Dialectical Approach to Film Form," in Film Form: Essays in Film Theory, ed., Trans. Jay Leyda (New York: A Harvest/HBJ Books, 1977), 49. 28. Kubelka, "The Theory of Metrical Film," 141. 29. Barnaby Dicker, "Twenty-First Century Flicker: Jodie Mack, Benedict Drew and Sebastian Buerkner," in Experimental and Expanded Animation: New Perspective and Practices, ed. Vicky Smith and Nicky Hamlyn (London: Palgrave Macmillan, 2018), 61.

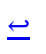


30. Tony Conrad, "Inside the Dream Syndicate," in Tony Conrad: Writings, ed. Constance DeJong and Andrew Lampert (New York: Primary Information, 2019), 306307. $\doteq$

31. Jonas Mekas, Conversations with Filmmakers: Movie Journal Columns 1961 1975 (Leipzig, Spector Books, 2018), 49.

32. Ibid. $\doteq$

33. Sitney, Visionary Film, 348. $\bullet$

34. From Tony Conrad' s The Flickerblue notebook, as quoted by Branden W. Joseph in Beyond the Dream Syndicate: Tony Conrad and the Arts After Cage (New York: Zone Books, 2008), 284.

35. Tony Conrad, "Tony Conrad on The Flicker," in Tony Conrad: Writings, ed. Constance DeJong and Andrew Lampert (New York: Primary Information, 2019), 97. 36. Joseph, Beyond the Dream Syndicate, 285. $\bullet$

37. Stockhausen articulated his findings and thought in his famous article "The concept of Unity in Electronic Music," trans. Elain Barkin, Perspectives of New Music 1, no. 1 (Autumn, 1962): 39- 48.

38. From footnote number 10 in Joseph, Beyond the Dream Syndicate, $434 . \subseteq$

39. As quoted in Joseph, Beyond the Dream Syndicate, 287. $\bullet$

40. Michael Nyman, Experimental Music: Cage and Beyond (Cambridge: Cambridge University Press, 1999), 11-13.

41. Note that Andy Warhol's concept of duration employed in his early films is completely different from Conrad's research around the same topic. For more on Andy Warhol' s films and its relation to structural film see Adams, Visionary Film, 349-351. 42. P. Adams Sitney' s description of the soundtrack, in Sitney, "Structural Film," 343. $\subseteq$

43. My use of the word fade out here does not refer to the common technique of the image dissolve, but rather to the idea that visual illusions start to fade out as the alternation of black and white images slows down, raising the awareness of different modes of perception. $\subseteq$ 
44. "Someone else saw a dragon. Another saw cubes, rotating geometrical shapes. These are specific images rather than, for instance, mandala patterns (which is a way of talking about a kind of random retinal activity that you usually feel with your eyes closed or under various other conditions)," Tony Conrad quoted in Mekas, Conversations with Filmmakers, $50 . \unlhd$ 45. George Maciunas, “On 'Structural Film' (by P. Adams Sitney)," Film Culture Reader, ed. P. Adam Sitney (New York: Cooper Square Press, 2000), 349. 46. Tony Conrad, "A Few Remarks Before I Begin," in Tony Conrad: Writings, ed. Constance DeJong and Andrew Lampert (New York: Primary Information, 2019), 164. 47. Joseph, Beyond the Dream Syndicate, 349. 48. Jean-Claude Lebensztejn, "Interview with Paul Sharits," in Ausstellung Paul Sharits: Eine Retrospektive, ed. Susanne Pfeffer (Kassel: Museum Fridericianum, 20142015), 259. $\uplus$

49. Tony Conrad explored flicker again in The Eye of Count Flickerstein (1967). $\bullet$ 50. Birgit Hein and Susanne Pfeffer, "The Image in the Structure: A Conversation," in Ausstellung Paul Sharits. Eine Retrospektive, ed. Susanne Pfeffer (Kassel: Museum Fridericianum, 2014-2015), 172.

51. P. Adams Sitney, Visionary Film. The American Avant-Garde, 1943 - 2000 (New York: Oxford University Press, 2002), 362.

52. Malcolm Le Grice, Abstract Film and Beyond (Cambridge: MIT Press, 1977), $106 . \boxminus$ 53. Branden W. Joseph, “A Crystal Web Image of Horror: Paul Sharit' s Early Structural and Substructural Cinema," in Ausstellung Paul Sharits: Eine Retrospektive, ed. Susanne Pfeffer (Kassel: Museum Fridericianum, 2014-2015), 205. 54. Letter from Paul Sharits to P. Adam Sitney, as cited by Joseph, "A Crystal Web Image of Horror," 205.

55. Sitney, "Structural Film," 345.

56. Sitney, Visionary Film, 348. $\doteq$

57. Paul Sharits, "N:O:T:H:I:N:G (1968) / From an Application for Grant," in Ausstellung Paul Sharits: Eine Retrospektive, ed. Susanne Pfeffer (Kassel: Museum 
Fridericianum, 2014-2015), 361.

58. Ibid. $\triangleq$

59. Paul Sharits, "Words per Page," in Ausstellung Paul Sharits: Eine Retrospektive, ed. Susanne Pfeffer (Kassel: Museum Fridericianum, 2014-2015), 376.

60. Ibid., 413 - 417.

61. Sharits, "Hearing : Seeing," 414.

62. Transcriptions are a series of musical scores hand painted by Sharits. He did not approached the work systematically by associating a note, a rest or a value to a colour, but rather he filled the spaces delimitated by the intersection of the lines with colour, suggesting the idea of temporal development of painterly principles rather than colourtone analogies. $\subseteq$

63. Joseph, "A Crystal Web Image of Horror," 204.

64. Rosalind Krauss, "Paul Sharits," in Film Culture, No. 65-66 - 1978: Paul Sharits, ed. Jonas Mekas (Montpelier, Vermont: Capital City Press, 1978), 99.

65. Joseph, "A Crystal Web Image of Horror," 211.

66. Richard M. Warren and Roslyn P. Warren, “Auditory Illusions and Confusions," Scientific American 223, no. 6 (December 1970): $35 . \Xi$

67. Joseph, “A Crystal Web Image of Horror," 211-212.

68. Jean-Claude Lebensztejn, "Interview with Paul Sharits," in Ausstellung Paul Sharits: Eine Retrospektive, ed. Susanne Pfeffer (Kassel: Museum Fridericianum, 20142015), 261-262.

69. Sharits, "Words Per Page," 370.

70. Tony Conrad, "Paul Sharits: Prescription and Collapsed Temporality," in Ausstellung Paul Sharits: Eine Retrospektive, ed. Susanne Pfeffer (Kassel: Museum Fridericianum, 2014-2015), 330.

71. Philip Alperson, “'Musical Time' and Music as an 'Art of Time' ," The Journal of Aesthetics and Art Criticism, 38, No. 4 (Summer, 1980): 414. 
72. My translation. "Extirpar al fantasma de las entrañas de la máquina poniendo en correlato un principio esencial de desmitificación -que cine no es movimiento de imágenes sino vibración luminosa," cited from Esperanza Collado Sánchez, Paracinema: La desmaterialización del cine en las prácticas artísticas (Arte y Derecho, Trama Editorial, S.L.), chap. 3, Kindle. $\_$ 